\title{
Higher education segregation in Spain: gender constructs and social background.
}

\author{
(Forthcoming in European Journal of Education)
}

\section{Hugo García-Andreu}

hugo.andreu@ua.es

\author{
Alejandro Acebal \\ alejandro.acebal@ua.es
}

Antonio Aledo

antonio.aledo@ua.es

Dpto. Sociología I e Instituto Universitario de Investigaciones Turísticas

Universidad de Alicante

Campus de San Vicente del Raspeig

Spain

Highlights

- We confirm the validity of the EMI theory

- There is a class effect in the horizontal stratification of the degrees

- Gender is the most determining factor in the choice of degree

- Horizontal stratification is influenced by vertical stratification of gender

- The consolidation of educational expansion has increased the class effect

\begin{abstract}
In developed societies, education has become a fundamental element of social stratification by providing access to jobs of greater social status, prestige and remuneration. This fact, altogether with the expansion of higher education systems, would seem to lead to the conclusion that economic modernization has come to put an end to the decisive influence of ascriptive factors on occupational achievement. However, the Effectively Maintained Inequality theory (EMI) states that horizontal stratification of academic disciplines and university degrees is a strategy of social differentiation mostly used by the most advantaged social classes in order to access the highest valued jobs in the labor market. This article aims at testing the validity of the EMI theory in a Spanish university taking as sample data spanning the decade (1994-2013) characterized by the expansion and consolidation of the Spanish higher education system. The results confirm the theory but in part they condition it to the
\end{abstract}


vertical stratification that alters the composition by sexes of the contingent of students of less advantaged social class that reaches the university. In this group, women predominate who have traditionally chosen degrees less valued by the market.

\section{Keywords:}

Inequality of educational opportunities; higher education expansion; educational choices; overeducation; sex-segregation; class-segregation.

\section{INTRODUCTION}

The constant expansion of the education system has been an essential factor in the economic development experienced by Western societies in the second half of the 20th century. For the Human Capital and Modernization theories, educational expansion, especially of tertiary studies, has played a fundamental role in economic growth and development by providing the skilled labor required by the industrial and postindustrial productive systems for the performance of increasingly more complex and advanced tasks (Bell, 1973, Becker, 1983, Schultz, 1983). In highly developed market economies, employers select the best trained candidates because the productivity and competitiveness of their businesses depend on it. The historical transition to advanced capitalist economies, characterized by an increase of educational opportunities and the professionalization of the human resources selection processes led many scholars to forecast the eventual demise of the influence of ascriptive factors in occupational achievement. Education was called to usher in an era of increasing freedom from the constraints of social origin. Some social scientists detected a weakening of the effects of social class origin on occupational achievement in favor of meritocratic criteria related to individual intelligence and performance, embodied in the type and level of education attained by individuals (Bell, 1972; Blau and Duncan, 1967; Treiman, 1970). In a context of increasing educational opportunities, social selection theory stated that the homogeneity of students increases in terms of skills, motivations and occupational aspirations with each transition in the education system, thereby reducing the influence of the students' social origin in occupational achievement (Boudon, 1974; Mare, 1980). In Spain, several authors have presented results consistent with the social selection theory. Carabaña (2004) analyzed the occupational achievement of university students taking into account their social origin and did not identify any difference attributable to social class. For this author, the social selection process was to be found in a previous moment, at the point of access to university (vertical stratification). More recently, Fachelli and Navarro-Cendejas (2014) have argued that, although the social origin is relevant when analyzing the occupational achievement of the population as a whole, when the analysis is limited to the university level, social origin has no influence on the structure of wages: only sex and the kind of jobs different degrees give access to would be significant. Nevertheless, the authors also 
recognize the need to carry out further studies that include an additional variable: the specific degree chosen by individuals. Numerous other works questioning the advancement of meritocratic criteria in both occupational achievement and educational attainment have also been published in parallel with these studies.

In regard to occupational achievement, some studies argue that social origin leads to overeducation through cultural and social capital. Educational degree and performance being equal, individuals who have been socialized in families with high cultural capital develop a range of skills that are not always available through formal learning processes and that are highly valued by employers (Marquis and GilHernández, 2015; Breen and Goldthorpe, 2001; Jackson, 2001; Rivera, 2012). Social capital also leads to differences in occupational achievement within the same educational level: Family or acquaintances' networks increase the potential job searching channels and have a strong weight when it comes to choose between candidates with similar professional profiles competing for the same post (Lin, 1999; Bálint, 2013; Brunello and Schlotter, 2011; Tholen et al., 2013; Marquis and Gilhernandez, 2015).

On the other hand, there are studies that focus on a previous stage, that is, in the process of acquiring the educational level (educational achievement). In this sense, some scientists have analyzed the inequality educational opportunities (IEO) among different social strata in a context of educational expansion. Two of the most influential theories are the Maximally Maintained Inequality (MMI) (Raftery and Hout, 1993) and the Effectively Maintained Inequality (EMI) (Lucas, 2001). The expansion of education would have theoretically created more opportunities but, according to the MMI theory, for these new opportunities to reach the lower classes, they must be first generalized or get to a "saturation point" among the more advantaged strata. In other words, as long as an educational level has not been generalized among the population, the upper class families will use all the resources at their disposal to ensure that that level of education still works to construct and maintain social differentiation and vertical stratification. The EMI theory goes a step further by pointing out how, when educational opportunities are generalized among different social classes, the upper class looks for qualitative elements through which to differentiate themselves from the rest of society (Lucas, 2001), such as the prestige of educational institutions or the fields/disciplines of degrees (horizontal stratification). In short, what the EMI theory comes to say is that as vertical stratification tends to diminish, horizontal stratification tends to increase.

This research aims at shedding light on the debate about the effects of the expansion of higher education systems on occupational achievement. Our starting hypothesis aligns with the EMI theory by affirming that, in the historical context of higher education expansion in Spain, the horizontal stratification of degrees functions as a strategy of social differentiation mainly used by the most advantaged social class in order to access occupations better valued in the labor market. To confirm this 
hypothesis, the present study analyzes the class effect in the choice of degrees with the worst/best success rate in the labor market. Taking into account the strong influence of gender in the choice of degree, we will pay special attention to the relationship between social class and gender cultural constructs in order to identify the concrete mechanisms by which the class effect operates. We use a sample of 112,303 first-year students from the University of Alicante (UA) (Spain) as case study, distributed throughout 18 academic years (from 1994-95 to 2012-13), the time span that witnessed the expansion and consolidation of the higher education system in Spain.

\section{BACKGROUND}

Access to post-secondary studies ${ }^{1}$ in Spain was significantly boosted by the devolution of education to autonomous regional governments by means of the Educational Reform Bill (Ley de Reforma Educativa, LRU) in 19832. Regional governments expanded faculty and schools in existing universities as well as created new ones. During the 90's, 15 public and 13 private new universities were established in Spain (Bricall, 2000, University Coordination Council, 2002), facilitating access to higher education for many Spaniards, and especially for women (Angoitia and Rahona, 2007). In parallel with the emergence of new centers, the offer of degrees was extended, turning the 90 's into a fundamental period for the expansion of the Spanish university system (de León and Cortázar, 1992, Pérez and Serrano, 1998, Angoitia and Rahona, 2007).

This expansion of the higher education system has facilitated the access of population to higher education. However, not all degrees are equally valued in the labor market. Regarding occupational achievement, the incorporation of graduates to the labor market, Spain stands out among the European countries for its high overqualification rate 3 . One of the reasons brought forward to explain this fact is the mismatch between tertiary educational expansion and the Spanish economy, with the latter failing to produce enough labor to absorb a significant part of the new skilled human capital (Baron \& Ortiz, 2011). Overqualification, though, is not a problem

1

In Spain almost all post-secondary education is taught in universities, so talking about higher education more or less amounts as talking about university education (Albert and García-Serrano, 2010; Mora, García-Montalvo \& García-Aracil, 2000

2

The transfer of higher education competences from the State Administration to the Valencian Regional Government was officially carried out on November $20^{\text {th }} 1985$ by Royal Decree 2633/1985

3

Overqualification occurs when employees have more training than is required for the job position. In Spain overqualification rate is $22 \%$ compared to an average of $13.2 \%$ in the OECD countries(OECD, 2007 in García Montalvo, 2009: 173) 
unique to Spain. A recent study carried out in 22 European countries (Reimer, Noelke \& Kucel, 2008) concluded that educational expansion has led to a generalized depreciation of the market value of arts, humanities and social sciences degrees, which translates into greater risk of unemployment and/or overqualification. The study shows how students with lower intellectual skills, through a process of self-selection and institutional classification, end up more likely enrolling in this kind of degrees since they are less challenging from the academic point of view. The theory of human capital explains this depreciation by pointing out to the low value these degrees have in the market. Different studies show how graduates in business, science or mathematics get above the average salaries, social sciences graduates are on the average, whereas graduates in the arts and humanities tend to earn below the average wages (Triventi, 2013a, Gerber \& Cheung, 2008). The reason for these salary differences is that different types of degrees represent different types of specialized human capital having a different value in the market in relation to their scarcity within a given economy (Daymont \& Andrisani 1984, Paglin \& Rufolo 1990, Gerhart 1990, Van de Werfhorst \& Kraaykamp 2001, Van de Werfhorst 2002, Shauman 2006). Human capital purposely formed to acquire advanced mathematical skills, on which the current economic growth is based, is more valued for its scarcity than human capital mainly formed on the basis of verbal skills.

In Spain, Biology, Geography, History and Social Work graduates are those showing a more problematic transition to the labor market. They are followed by Psychology, Sociology and Education. These degrees correspond to those with the highest unemployment rate, lowest activity rate, highest proportion of temporary and part-time contracts, lower salaries and less qualified occupations. In the opposite end we find technical disciplines graduates, in particular industrial and civil engineers and architects, followed by agronomists, quantity surveyors (building engineers) and computer scientists. (Career after Higher Education: a European Research Study, CHEERS, García Montalvo, 2001: 162 and 2009: 178).

Interpreted in the light of EMI theory (Lucas, 2001), the recent expansion of the Spanish higher education system should have reduced (Mora, 1997, Mora, GarcíaMontalvo \& García-Aracil, 2000), although not totally eliminated (Rahona, 2009), vertical stratification in the education system increasing, at the same time, the horizontal stratification thus creating opportunities of social and labor differentiation associated with the choice of degree. The question we want to answer is: who takes advantage of these opportunities? Or, put it in sociological terms, does the choice of degrees with potentially better employment conditions respond to some sort of class effect? Traditional variables of social stratification analysis include ethnicity, social class and sex/gender. Ethnicity is a variable with low explanatory power in the Spanish case, at least in regard to our subject of study, since Spain is a quite homogeneous country from the ethnic point of view and its largest ethnic minority, the gypsies, barely access higher education (vertical stratification). Thus, in this work we will focus on the social class and sex/gender variables. With regard to social class, in Spain there has traditionally been an overrepresentation of the least advantaged social classes in the academic disciplines least valued in the market (Salvador and García-Valcárcel, 1989, Monreal et 
al., 1982; Latiesa, 1986). More recent studies show this situation hasn't changed much over the years: "There continues to be a greater presence of students with a low-skilled manual worker family background in the social sciences, humanities and vocational training degrees as compared to health sciences, and above all, experimental sciences"(Ariño, et al., 2011). Several explanations have been proposed. The 'diversion hypothesis' (Brint and Karabel, 1989) defends that the educational system itself shapes and even promotes a self-selection process by which students from the less advantaged classes end up, on average, more likely "choosing" the degrees (and universities) with the lowest prestige and market value. In this process of educational self-segregation, the educational level of parents is of great importance (Triventi, 2013ab). Families from privileged social classes are better equipped with the material and cultural resources which are necessary to take advantage of the available opportunities for social differentiation (Haim \& Shavit, 2013), including having more and better information about the stratified system of wages and its relation with certain university degrees (Paulsen, 2001). Aversion to risk, another factor that correlates with social class (in this case the fear of not being able of completing the degree) may also play a part in this overrepresentation of lower/working classes in the degrees least valued by the market (Breen and Goldthorpe, 1997, Triventi, 2013ab). Students of advantaged social classes have a lower aversion to the risk of failure (because their opportunity cost is lower) so they dare to choose more demanding university degrees that eventually lead to more demanded jobs in the labor market. On the contrary, the least advantaged social classes have a greater aversion to the risk of failing because higher education is a very important family investment which, thus, has a high opportunity cost.

If we now take into account sex and gender instead of class, we observe that men are also overrepresented in the degrees with the highest labor market value. Sex/ gender, therefore, is a relevant variable when interpreting horizontal stratification and, as we'll see, its influence is mediated by social class. In most Western countries, including Spain (Navarro-Guzmán and Casero-Martínez, 2012), women are underrepresented in STEM-fields (science, technology, engineering and mathematics) and the sex/gender gap is particularly significant in engineering (Carabaña, 1984 OECD, 1986, DiPrete and Buchmann, 2013, Charles and Bradley, 2009, Barone and Ortiz, 2011). A few decades ago it was thought that the days of this kind of sex/gender differences were numbered. Encouraged by a revision of the Theory of Modernization and the analysis of the World Values Survey (Inglehart, 1997), the gradual erosion of sex/gender differences in the choice of university degree was predicted by many (Jackson, 1998, Ramirez \& Wotipka, 2001). These authors foretold an increasing presence of women in degrees traditionally dominated by men as their massive access to higher education should help foster a female empowering process eventually leading to sex/gender balanced representation. Charles and Bradley $(2002,2009)$ point out that these predictions have miserably failed because they underestimated the strength of an essentialist gender ideology which clings to the idea of the existence of innate differences between men and women (women and men are "equal but different"). What these authors point out is that against an existing social background where this gender ideology exerts a significant influence in different aspects of life, the current value given to self-expression and self-realization still tends to materialize in the adjustment 
of individuals to prevailing gender stereotypes. Thus, the socially valued right to selfexpression is used by female students to choose those university degrees labeled as "feminine" because they help them build their gendered identity as women. According to the same authors, two other factors contribute to the explanation of the perseverance of horizontal stratification by sex/gender: 1) the expansion of the university degrees offer and the configuration of "gendered" formative paths; 2) the growth of the tertiary economic sector and the greater demand for female labor that comes with it.

In this process of construction of an essentialist gender ideology, socialization plays a fundamental role by unconsciously developing a penchant towards degrees that give access to professions considered culturally appropriate to each gender (Francis, 2000). However, since traditionally masculine degrees have a higher social value than traditionally feminine ones, it is more likely for a family to encourage a girl to choose a traditionally male degree than vice versa. On the contrary, for men, choosing a traditionally female degree leads to loss of status and prestige (Croxford, 1994). GabayEgozi, Shavit and Yaish (2014), after reviewing the different conditioning factors affecting horizontal stratification by sex/gender, conclude that, in addition to differential socialization and cultural conditioning factors, the choice of degree is also influenced by rational choice factors: women tend to attribute a lower practical value and a higher risk to STEM-fields (rational choice motivations).

In the Spanish context, research has also been carried out within the theoretical framework of the essentialist gender ideology. The Spanish studies point, basically, in the same direction as those conducted in other Western countries. López-Sáez (1985) highlighted the usefulness of psychosocial variables in explaining the gender differences, specifically stressing the importance of cultural factors. It is interesting to emphasize that, in that same work, the author points out to a relationship between social class and sex/gender that is not commonly found in the rest of literature: the author recognizes a certain correlation between sex/gender and socioeconomic variables in the choice of degree, by pointing out how the group of female students who atypically chose engineering, an"out-of-their-gender choice", "present a favorable situation with regard to studying the chosen degree that has to do with the educational level and job of parents and a family tradition in the same career"(López-Sáez, 1985: 169). On the other hand, as far as male students who make an atypical choice for their gender, in this case pedagogy, are concerned "is the group with the worst situation regarding the chosen degree and the educational level and job of parents"(López-Sáez, 1985: 169).

Some recent studies also address the relationship between social class and sex/ gender. Berggren's study (2008) reveals how, since 1960, women in Sweden have dramatically increased their presence in the most valued degrees. Hence, in this country, according to the author, we could no longer speak, with the sole exception of engineering studies, of degrees dominated by men. This change is accounted for by referring to the fact that women are now economically independent and that, consequently, families of advantaged classes encourage their daughters to enroll in degrees that allow them to reproduce the status and professional careers of their families and, especially, of their mothers. These conclusions, when introducing the social class 
factor, would come to diminish the enormous influence that has been acknowledged to gender in horizontal stratification, at least in those societies where women can be and are economically independent. Regarding our paper's approach, Berggren's research (2008) only reinforces our general starting hypothesis, namely, that horizontal stratification of academic disciplines and university degrees is a strategy of social differentiation used mostly by the most advantaged social classes to access the occupations best valued in the labor market.

From the studies discussed above we can establish the following research hypotheses:

Hypothesis 1.- The most advantaged social class is overrepresented in the degrees most valued by the labor market. This hypothesis is based on the following literature: for the Spanish case in Salvador and García-Valcárcel, 1989; Monreal et al., 1982; Latiesa, 1986; Ariño, et al., 2011; for the most general international context in Triventi, 2013ab; Haim \& Shavit, 2013; Paulsen, 2001; Breen and Goldthorpe, 1997.

Hypothesis 2.- The choice of degree continues to be strongly conditioned by gender constructions ("female" and "male" degrees). This hypothesis is based on the following literature: For Spain in Navarro-Guzmán and Casero-Martínez, 2012; Grañeras, 2003; Carabaña, 1984; for the most general international context in OECD, 1986; DiPrete and Buchmann, 2013; Charles and Bradley, 2002 and 2009; Barone, 2011; Francis, 2000; Croxford, 1994; Gabay-Egozi, Shavit, and Yaish, 2014.

Hypothesis 3.- Parents of the most advantaged social class encourage their daughters to choose better degrees (or those best valued by being traditionally male (Grañeras, 2003)) to perpetuate their social position. Social class counteracts, in this case, the prevailing cultural construct of gender (Berggren, 2008).

Hypothesis 4.- Overrepresentation of the least advantaged social class in the least valued degrees (Hypothesis 1) depends to a large extent on the relative weight of female students in the said category. The reasons that support this hypothesis are, on the one hand, the combined high probability of women generally choosing the least valued degrees (H2) and men choosing the best ones and, on the other hand, the fact that women of the less advantaged social class don't get the same amount of encouragement from their social environment to challenge the socially constructed gender roles that women of the most advantaged social class.

\section{METHOD}

This study is based on the assumption that the social origin of a person conditions its insertion in the labor market through the type of university degree he or she has studied. This approach rests on two premises: 1) the ability of educational degrees in modern and meritocratic societies to condition social stratification; 2) the fact that there is a class bias/effect underlying the educational decisions people make. The 
first premise has been sufficiently substantiated in the introduction. In this section, given its methodological implications, we will focus on the second. Class analysis is presented as a useful and necessary analytical-conceptual framework for the study of social stratification against those approaches that assume the dwindling effects of class in the dynamics of postindustrial welfare societies. Supporters of class analysis argue that in order to understand the distribution of socially valued resources (high status and high wages jobs in our case) it is not enough to take into account individual, family or community factors: it requires a deeper look into the underlying class structure (Portes, 2013). Class analysis has generated intense academic debates about its epistemological validity while at the same time producing numerous proposals for its operationalization, most of them focused on employment and the occupational structure (Crompton, 1994). One of the main criticisms class analysis has encountered regards class action, that is, the question of whether, in societies with a complex and highly specialized division of labor, there is a social identity shared by the members of each social class that results in a coordinated political action. In the face of these criticisms, Crompton points out that in contemporary societies where a high degree of inequality persists "it is probable that work has declined as an important source of social identity, but it still constitutes the most significant determinant of the material well-being of the majority of the population"(Crompton, 1994: 37). Some other recent works, such as the European Socio-economic Classification (Rose and Harrison, 2014), specifically developed and tested for use in EU comparative research, sustain this thesis. This study concludes that "the life-chances of individuals and families are largely determined by their position in the labor market and occupation is taken to be its central indicator; that is, the occupational structure is viewed as the spine of the stratification system" (Rose and Harrison, 2014: 4). Once occupation is accepted as an indicator of class ${ }^{4}$, the problem of how to elaborate aggregates of occupations remains. There has been an intense debate on this issue (Portes, 2013) that has led some authors to support the merging of the social class and occupation categories on the grounds that organizational strategies and lifestyle tend to converge among members of a given occupation (Grusky and Sorensen, 1998, cited in Portes, 2013). For authors such as Portes (2013) this disaggregation entails an excessive simplification which reduces the explanatory power of the concept. Portes' approach is articulated around the economic and political power variables as defining elements and aggregators of social class. Data collected for this research does not allow to construct the aggregates proposed by Portes, since we could only obtain the occupation and educational level of parents, as this was the only possible information students could provide through the University of Alicante registration forms. Neither would it be the most appropriate, in our case, to analyze the class effect using exclusively the occupation variable as a proxy of social class, as proposed by some authors (Grusky and Sorensen, 1998), because some of the categories on the UA registration form are rather broad or even ambiguous. There is a high

4

Similar research to the one presented in these pages has also been carried out using the educational level of parents as a proxy for social class (Triventi, 2013ab). 
probability that under a label such as "Private or public company management" respondents might have included occupations such as small retail businesses owners or self-employed professionals and not only big or medium sized company CEOs. Only that can explain the large number of students that ticked this category. In order to avoid this kind of inaccuracies we could have simply resorted to using the educational level of parents as social class proxy as other authors have done (Triventi, 2013ab). This methodological approach is grounded in the assumption that, for the time span analyzed (from 1994 to 2013), the educational level of parents, specifically when having higher education, can be considered a class factor since in those years Spanish higher education system was still in a developing phase. However, we have deemed more accurate to go a step further, constructing a new variable that combines the educational level and the type of occupation of parents ${ }^{5}$. Through a multivariate analysis (see Annex III) we have proven that having at least one parent who fulfills both criteria of "Private or public company management" and "Higher studies" statistically increases the probability of choosing a degree with a high rate of success in the labor market. These students will be classified as the "most advantaged social class" category6, the rest of cases being classified in the category of "least advantaged social class". This dichotomous grouping of the collected data is not intended to objectively reflect reality. We are well aware of the enormous empirical heterogeneity existing particularly within the so-called "less advantaged social class". We also acknowledge that a classification of data into a more complex set of social class categories would allow a richer and more nuanced analysis. However, we have encountered insurmountable methodological difficulties in trying to apply other social class classification schemes (Erikson and Goldthorpe, 1992) to our data because of their methods of collecting data and/or their classifications of occupations that are too ambiguous and wide to differentiate between middle and lower class. In any case, we firmly believe this dichotomous classification does not invalidate our results, considering that our objective is to test the EMI theory against our data (Lucas, 2001). EMI theory highlights the existence of differentiation strategies implemented to a greater extent by the most advantaged social class in a context of educational expansion. Hence, the most important thing to test our hypothesis is to isolate those students belonging to the most advantaged social class from the bulk of overall data. Our two variables are supported by the Logit Binomial analysis and a bivariate analysis has been run. Results are presented in the following section.

The sample has been obtained from the University of Alicante database and more specifically from the personal background information students provide during the registration process. We have analyzed records spanning 18 academic years (from

5

To assess in detail the process by which we have come to establish six categories of occupation and three educational levels see Annex I and II.

6

This category corresponds closely with the upper social class category used in similar works (Berggren, 2008). This classification, based on the "Swedish socio-economic status (SES) index", is closely related to the class scheme of Erikson and Goldthorpe (1992). The upper middle class (SES 1-Upper-middle class), as it is called in the study, includes top-level professionals, managers, civil servants and freelancers with an academic degree. 
1994-95 to 2012-13) corresponding with the period of expansion and consolidation of the higher education system in Spain. Two samples were used for the study: a larger one consisting of 112,303 students from all the undergraduate degrees offered by the university $^{7}$, and a smaller one $(32,910)$ which only takes into account the students enrolled in degrees which, according to the CHEERS study for Spain (Career after Higher Education: a European Research Study in García Montalvo, 2001: 162 and 2009: 178), have the better and worse success rates of transition to the labor market. Taking into account characteristics such as the unemployment and activity rate, type of contract, hours of work and salary, graduates of the technical disciplines, in particular industrial and civil engineers, architects, agronomists, quantity surveyors and computer scientists present the highest success rate in the labor market. On the other hand, graduates in Biology, Geography, History and Social Work show the most problematic transition to the labor market, followed by psychologists, sociologists, and education graduates. These degrees correspond to those with the highest unemployment rate, lowest activity rate, highest proportion of temporary and part-time contracts, lower salaries and less qualified occupations. Only a few of the highest rated degrees in the CHEERS study (Architecture, Building, Computer and Civil Engineering) are taught at the UA whereas the group of UA degrees rating lowest in the CHEERS ranking is more numerous (Biology, Geography, Education, Psychopedagogy, Sociology and Social Work). These ten degrees are the ones making up the reduced sample.

\section{RESULTS}

Table 1 present the distribution by sexes and social class of first enrollment students in our case study.

Tabla 1. Sexo y clase social del alumnado

\begin{tabular}{|c|c|c|}
\hline SEX & & Frequency (\%) \\
\hline & Women & $63253(56.3 \%)$ \\
\hline
\end{tabular}

7

Architecture, Building Engineering, Criminology, Business Studies (until 2009/10), Nursing, Statistics (until 1996/97), Human Nutrition and Dietetics, Optics and Optometry, Labor Relations and Human Resources, Social Work, Tourism Studies; Spanish language and literature (previously Hispanic Philology), Management and Public Administration, Multimedia Engineering (Computer Engineering); Civil Engineering, Geology (Geological Engineering); Chemical Engineering, Chemistry, Sound and Image Engineering, Biology, Sports Sciences, Technical Engineering in Public Works, Business Administration and Management, Labor Sciences (began phasing out in the 2013/14 academic year), Economics, Geography, Urban and Landscape Planning, History, Humanities, Advertising and Public Relations, Sociology, Translation and Interpreting, Education (Infant and Primary), Medicine (years 95/96 and 96/97),Psychopedagogy (began phasing out in the year 2013/14). 


\begin{tabular}{|c|c|}
\hline Men & $49050(43.7 \%)$ \\
\hline Total & $112303(100 \%)$ \\
\hline SOCIAL CLASS & Frequency $(\%)$ \\
\hline Most advantaged social class & $11501(11.5 \%)$ \\
\hline Less advantaged social class & $88562(88.5 \%)$ \\
\hline Total & $100063(100 \%)$ \\
\hline Non classified & 12240 \\
\hline
\end{tabular}

Source: Authors, from data by the University of Alicante

Data shown in Table 1 are consistent with the literature. There is an overall overrepresentation of women and students from the less advantaged social classes. In this sense, it should be borne in mind that the UA can be ranked as a "provincial" university and, therefore, it is quite likely that a significant part of the local upper class students choses to "flee" to more prestigious universities in bigger cities or abroad. This assumption does not put into question the results of our study since our analysis of overrepresentation is based on the average weight of each social class in the university's enrollment. Could the flee of the upper classes towards more prestigious universities outside the province be proven by data it would only reinforce the EMI hypothesis because this theory points out that when educational opportunities are widespread among different social classes, the upper class always looks for qualitative elements to maintain social differentiation (Lucas, 2001): in this case, the higher prestige of more cosmopolitan/international universities (horizontal stratification).

Table 2 shows detailed data on the total number of enrollments at the UA during the eighteen academic years analyzed (from 95-96 to 2012-13) in the "best" and "worst" degrees established in the CHEERS study (García Montalvo, 2001). Information is organized by sex and social class.

Table 2. Distribution of students in the best and worst valued degrees.

\begin{tabular}{|c|c|c|c|c|}
\hline \multirow{3}{*}{$\begin{array}{l}\text { Best / worst } \\
\text { valued degrees in } \\
\text { the labor market }\end{array}$} & \multicolumn{2}{|c|}{ SEX } & \multicolumn{2}{|c|}{ SOCIAL CLASS } \\
\hline & Men & Women & $\begin{array}{l}\text { Less advantaged } \\
\text { social class }\end{array}$ & $\begin{array}{l}\text { Most advantaged } \\
\text { social class }\end{array}$ \\
\hline & & & $X=88.5 \%$ & $X=11.5 \%$ \\
\hline Archiitecture & 1245 (56.6\%) & $954(43.4 \%)$ & $1220(60.3 \%)$ & $802(39.7 \%)$ \\
\hline $\begin{array}{l}\text { B u i l d i n g } \\
\text { Engineering }\end{array}$ & $2804(64.1 \%)$ & 1572 (35.9\%) & $2720(73.1 \%)$ & 999 (26.9\%) \\
\hline $\begin{array}{l}\text { M u l t i m e d i a } \\
\text { Engineering }\end{array}$ & $7400(85.0 \%)$ & 1302 (15.0\%) & 5005 (73.0\%) & $1848(27.0 \%)$ \\
\hline
\end{tabular}




\begin{tabular}{|c|c|c|c|c|}
\hline Civil Engineering & 792 (77.9\%) & $225(22.1 \%)$ & $638(63.1 \%)$ & $373(36.9 \%)$ \\
\hline $\begin{array}{l}\text { Average } \\
\text { enrollment in the } \\
\text { best valued } \\
\text { degrees }\end{array}$ & - & - & $X=67.4(-21.1)$ & $X=32.6(+21.1)$ \\
\hline Social Work & $502(14.2 \%)$ & $3038(85.8 \%)$ & $2615(81.8 \%)$ & $582(18.2 \%)$ \\
\hline Biology & $1454(39.9 \%)$ & $2191(60.1 \%)$ & 2442 (72.9\%) & $907(27.1 \%)$ \\
\hline Geography & $1950(56.9 \%)$ & 1479 (43.1\%) & 2502 (79.9\%) & $628(20.1 \%)$ \\
\hline Sociology & $933(37.1 \%)$ & $1583(62.9 \%)$ & $1758(77.1 \%)$ & $521(22.9 \%)$ \\
\hline Education & $2623(25.0 \%)$ & 7890 (75.0\%) & 7401 (78.7\%) & $2003(21.3 \%)$ \\
\hline Psychopedagogy & 405 (21.0\%) & 1519 (79.0\%) & 1157 (74.1\%) & 448 (27.9\%) \\
\hline $\begin{array}{l}\text { A } v \text { e } r \text { a e } \\
\text { enrollment in the } \\
\text { worst valued } \\
\text { degrees }\end{array}$ & & & $X=77.2$ & $(+11.3)$ \\
\hline
\end{tabular}

Source: Authors from data by the University of Alicante

Despite the fact that the students belonging to the most advantaged social class is on average $11.5 \%$ of the total number, they are overrepresented in all the best valued degrees: Architecture (39.7\%), Building Engineering (26.9\%), Multimedia Engineering $(27 \%)$ and Civil Engineering (36.9\%). On the contrary, students belonging to the least advantaged social class are significantly underrepresented in the best degrees, well below their total relative weight in the university population $(88.5 \%)$. With regard to the worst valued degrees, students of the most advantaged social class are again overrepresented relative to their overall weight (11.5\%). This overrepresentation may be pointing to the fact that not all degrees considered least valued on the basis of certain objective indicators (García Montalvo, 2001) are always and in all circumstances a bad choice. Although in a lesser extent than those the so-called best degrees, some of the least valued degrees may be sound strategical choices for some students belonging to the most advantaged social class when the limited access they provide to their niche labor markets is set off by cultural (Marqués and Gil-Hernández, 2015; Breen and Goldthorpe, 2001, Jackson, 2001, Rivera, 2012) and social (Lin, 1999, Balint, 2013, Brunello and Schlotter, 2011, Tholen et al., 2013, Marqués and Gil-Hernández, 2015) capital (i.e. studying an Education degree when your father is the owner of a prestigious private school). It is equally very significant that students of the least advantaged social class are also underrepresented in the least valued degrees. Thus, students of the most advantaged social class are, as a matter of fact, overrepresented in both the best and the worst degrees, and just the opposite happens to the students of the less advantaged social class. It is also worth noting that differences in percentages of over and underrepresentation are not the same for the best and the worst degrees. While in the best ones students of the most advantaged social class are $21.1 \%$ above their overall relative weight, in the worst degrees this figure drops to $11.3 \%$. The overrepresentation 
of the most advantaged social class students in both the best and the worst degrees is, thus, advantageous in general terms, since it is much larger (almost double) in the best degrees than in the worst.

If we analyze the longitudinal evolution of enrollment in the best and worst valued degrees, disaggregating by social class, we observe several interesting things (charts 1 and 2): 1) The representation of students belonging to the most advantaged social class in the best degrees (chart 1) has increased over time, with a significant jump in the 2000-01 academic course that consolidates in subsequent years. In other words, data seem to show that the distribution of the classes in the best degrees is quite constant and stable over time; 2) The most advantaged social class has also experienced an increase in representation in the worst degrees over the years (chart 2), with a strong change in the 2000-01 academic year, similar to what total figures show (table 2); this increase, though, is lower than in the best degrees case. Again data also show a consistent pattern over time. In both cases, the significant and sudden change that takes place during the 2000-01 academic year stands out. This was the year enrollment in the Spanish university system peaked, putting an end to the historical upward trend. As the arrival of students to the university slowed down and the so far expanding higher education system entered a plateau phase, representation of students from less advantaged class families fell, especially those who chose the best valued degrees, and the gap was filled by students from more advantaged class families. In the years preceding and following the enrollment peak the process of higher education expansion, fueled, among other factors, by the massive enrollment of women, the high profitability of individual investment in education (better salaries and lower unemployment rate) and the creation of new universities (Angoitia and Rahona, 2007), may have contributed to keep a low level of horizontal stratification by degrees. This is consistent which results presented by Carabaña (2004). It would be later on during the plateau phase, when horizontal stratification by social class began to surface.

Chart 1. Evolution of enrollment (male \& female) in the best valued degrees disaggregated by social class 


\section{Chart 2. Evolution of enrollment (male \& female) in the worst valued degrees disaggregated by social class}

Using the data presented so far, we can start testing our first hypothesis (H1), the one assuming that "advantaged social classes are overrepresented in the degrees most valued by the labor market". In our case, this overrepresentation has even grown with the passage of time in favor of the most advantaged social class. However, contrary to what the EMI had predicted, this overrepresentation seems to occur in the plateau phase of the higher education system evolution rather than in the expanding one. It is at this point in time when the horizontal stratification of academic disciplines and degrees intensifies its function as a mechanism for social differentiation. Faced with the challenge to counteract the growing competition caused by the expansion and "democratization" of higher education, horizontal stratification strategies like this are likely to be embraced by the most advantaged social classes in order to preserve their access to the best valued occupations in the labor market.

However, as we have seen in the literature review, social class is not the only variable that influences horizontal stratification. Gender also determines the choice of degree. In the present study, the influence of the gender variable is presented through two types of analysis. On the one hand, in the binomial logit analysis (Annex III), "sex" (culturally shaped by "genderized" social roles) stands out as the variable with the highest incidence in the choice of degree. Specifically, the model predicts that the probability of enrolling in degrees with more a difficult transition to the labor market is 6.943 times higher in women than in men. Using other indicators in the table, we observed that a male student has a 1.26 times higher probability of taking one of the best degrees than one of the worst. For female students this probability drops to 0.18. Finally, as far as the sex/gender variable is concerned, the binomial logit analysis predicts that $56 \%$ of men will choose to enroll in the best degrees, as opposed to only $15 \%$ of women. The detailed analysis by degrees (Table 2 ) also shows that women are underrepresented in the best degrees in relation to their relative weight in the total number of UA students. Although the UA female students amount to $56.3 \%$ of the total in the 18 years analyzed, in the best degrees they always present lower figures, ranging from $43.4 \%$ in Architecture to $15 \%$ in Multimedia Engineering. On the contrary, in the worst degrees, female students are, with the sole exception of Geography (43.1\%), 
above their relative weight in the UA university population: $85.8 \%$ in Social Work, $79 \%$ in Psychopedagogy, 75\% in Education, 62.9\% in Sociology and 60.1\% in Biology. However, it is worth noting that the average data of the analyzed years could be hiding year-on-year changes that could point out to a gradual reduction in the levels of horizontal segregation by sex, due, in part, to the empowerment process the massive incorporation of women to the university entails (Ramirez \& Wotipka, 2001; Jackson, 1998) and/or the gradual loss of strength of the essentialist gender ideology (Charles and Bradley, 2002, 2009). To verify this, we have disaggregated data by academic year (chart 3). This chart shows a significant increase in women enrollment in the best degrees over the years, from $23.6 \%$ in $95-96$ to $32.6 \%$ in $2012-13$. Most significantly, this increase $(9 \%)$ is almost three times higher than the growth in the total number of women enrolled in the university (3.2\%), pointing out to a change in the motivations for choosing a degree. This figure, though, is still far from reflecting the weight of female students in the university as a whole.

\section{Chart 3}

$\%$ of female students relative to total first enrollment and enrollment in the best degrees

Blue column ( $\%$ in best degrees)

Orange column $(\%$ total enrollment $)$

Source: Authors from data by the University of Alicante

Therefore, we can confirm our second hypotheses (H2), the one which states that the choice of degree continues to be strongly conditioned by gender social constructs ("female" and "male" degrees). In terms of horizontal stratification and occupational achievement this means that women are more likely than men to enroll in degrees with the least value in the labor market. However, we must be very attentive to the evolution of enrollments in the years to come since, in the light of data, the slow but steady increase of female students in the best degrees does not seem to have plateaued yet and may eventually bring representation close to a gender balance.

Are all social classes equally represented in this recent increase in the enrollment of women in the best degrees, or on the contrary, is there a class bias? Some authors (Berggren, 2008) gave us some clues that allowed us to construct our third hypothesis (H3): advantaged social classes encourage their daughters to choose the best degrees to perpetuate their social position, fulfilling at the same time the greater expectations for personal and economic independence younger generation of women have. This parental encouraging counteracts the cultural gender bias still predominant in the population as a whole. To verify this hypothesis, we will now check if data show a higher probability of 
choosing some of the best degrees in the group of advantaged social class female students, thus demonstrating that class interests and the influence of middle/upper class professional mothers or female relatives as role models are able to counteract the general gender social constructions.

Table 3. Distribution between worst and best degrees according to social class and sex

\begin{tabular}{|c|c|c|c|c|c|}
\hline SEX & & & $\begin{array}{c}\text { Less } \\
\text { advantaged } \\
\text { social class }\end{array}$ & $\begin{array}{c}\text { Most } \\
\text { advantaged } \\
\text { social class }\end{array}$ & Total \\
\hline \multirow[t]{3}{*}{ Women } & \multirow{2}{*}{ DEGREE. } & Worst degrees & $14521(91.7 \%)$ & $1307(8.3 \%)$ & $15828(100.0 \%)$ \\
\hline & & Best degrees & $2815(83.1 \%)$ & $573(16.9 \%)$ & 3388 (100\%) \\
\hline & Total & & $17336(90.2 \%)$ & $1880(9.8 \%)$ & $19216(100 \%)$ \\
\hline \multirow[t]{3}{*}{ Men } & DEGREE & Worst degrees & $6211(90.0 \%)$ & $690(10.0 \%)$ & $6901(100 \%)$ \\
\hline & & Best degrees & $8650(85.3 \%)$ & $1491(14.7 \%)$ & $10141(100 \%)$ \\
\hline & Total & & $14861(87.2 \%)$ & $2181(12.8 \%)$ & $17042(100 \%)$ \\
\hline
\end{tabular}

Source: Authors from data by the University of Alicante

The data shown of Table 3 supports the Effect of social class in the female students' choice of degree. Comparatively the presence of Female students of most advantaged social class in best degrees $(16,9 \%)$ it's above of male students in the same degrees and of the same social class $(14,7 \%)$. Besides, in the case of worst degrees, female students of most advantaged social class are $(8,3 \%)$ under male students $(\mathbf{1 0 \%})$. In other words, the effect of social class when it comes to directing its members towards the best degrees and avoiding the worst degrees is especially noticeable in the case of female students. In short, the gender stereotype that leads women to choose less valued degrees is clearly countered by family factors and $\mathrm{H} 3$ is supported by data.

Taking all these results into account, we can better see the logic leading to our fourth hypothesis (H4): the overrepresentation of the most advantaged social class students in the best degrees is closely related to the relative weight of men and women from the UA sample within that particular social class category. In order to contrast this fourth hypothesis, Table 4 has been elaborated. It shows that in the least advantaged social class the weight of women $(57.9 \%)$ is 6.3 points higher than in the most advantaged social class (51.6\%). Although this figures are not conclusive, it can be argued that the overall slightly higher weight of male students in the most advantaged social class category favors its overrepresentation in the best degrees, taking into account, as explained above, the greater probability of men to choose better degrees and the encouraging effect of class that also increases that probability in women of the more advantaged social class.. 
Table 4

\begin{tabular}{|c|c|c|c|c|c|}
\hline & & Women & Men & $\begin{array}{c}\mathrm{T} \\
\mathrm{o} \\
\mathrm{t} \\
\mathrm{a} \\
\mathrm{l}\end{array}$ & Total \\
\hline \multirow[t]{2}{*}{ Social class } & $\begin{array}{l}\text { LESS advantaged } \\
\text { social class }\end{array}$ & $\begin{array}{c}51262 \\
(57.9 \%)\end{array}$ & $\begin{array}{c}37300 \\
(42.1 \%)\end{array}$ & & $\begin{array}{c}88562 \\
(100.0 \%)\end{array}$ \\
\hline & $\begin{array}{l}\text { MOST advantaged } \\
\text { social class }\end{array}$ & $\begin{array}{c}5937 \\
(51.6 \%)\end{array}$ & $\begin{array}{c}5564 \\
(48.4 \%)\end{array}$ & & $\begin{array}{c}11501 \\
(100.0 \%)\end{array}$ \\
\hline \multicolumn{2}{|c|}{ Total } & $\begin{array}{c}57199 \\
(57.2 \%)\end{array}$ & $\begin{array}{c}42864 \\
(42.8 \%)\end{array}$ & $\begin{array}{c}1 \\
0 \\
0 \\
0 \\
6 \\
3 \\
( \\
1 \\
0 \\
0 \\
. \\
0 \\
\% \\
)\end{array}$ & $\begin{array}{l}100063 \\
(100 \%)\end{array}$ \\
\hline
\end{tabular}

Source: Authors from data by the University of Alicante

Another way to confirm our fourth hypothesis is to verify, with a linear discriminant analysis, to what extent the weight of the group of less advantaged social class women correlates with the weight of the total number of less advantaged social class students (men and women). Figure 4 shows a correlation of 0.958 , a very robust one.

\section{Chart 4}

Linear regression: relation between the historical series of total enrollment of least advantaged class students in the worst valued degrees and evolution of \% least advantaged class female students in all degrees 


\section{Chart 5}

\section{Linear regression: relation between the historical series of total enrollment of least advantaged class students in worst valued degrees and evolution of \% least advantaged class male students in all degrees}

Source: Authors from data by the University of Alicante

However, Figure 5 also shows a high correlation (0.9352) between the evolution of the percentage of less advantaged social class men in worse degrees and the percentage of less advantaged social class men in all degrees. This difference may help explain the total overrepresentation of the most advantaged social class. Differences in the correlation have a much greater multiplier effect when applied to the least advantaged social class category because its women population has a very significant weight (6.3\% higher than in the most advantaged social class category). The social class factor that counteracts the adjustment to the social constructions of gender (H3) is weaker in the students of less advantaged social class category, thus contributing to explain the difference.

\section{CONCLUSIONS}

The empirical data collected and analyzed in this paper allow us to validate the Effectively Maintained Inequality theory (Lucas, 2001). We have verified how the horizontal stratification of university degrees constitutes an opportunity for social differentiation mainly used by the most advantaged social class to access the occupations best valued in the labor market. This confirmation of the EMI theory comes with some nuances, though, which are necessary to adjust the theory to our study case. Contrary to what EMI predicts, our study shows that this horizontal stratification emerges at the time of stabilization and consolidation of the higher education system development, after enrollments have peaked, rather than during the expansive phase. As a consequence students from the most advantaged social class are (on average) represented in the best degrees far above what would be expected from their specific weight in the total student population studied. Our analysis has identified and tested some of the concrete mechanisms that cause this overrepresentation. We have discovered how gender constructs, the most influential factor when choosing degrees, have a weaker influence on the most advantaged social class compared to the least advantaged. That is, the influence of gender is modulated by the influence of social class. Our results show that in the most advantaged social class distribution by sex is very close to a balance $(51.6 \%$ women / $48.4 \%$ men). In this particular social class 
being male or female does not seem to significantly alter the probability of reaching university (absence of vertical stratification by sex/gender). On the contrary, in the less advantaged social class category, figures show a significantly higher weight of women $(57.9 \% / 42.1 \%)$ which could be due to two factors: 1) Women encounter more difficulties in accessing the labor market (higher unemployment rates); this means that the opportunity cost of pursuing post-secondary education is much lower for working class women than for men and, instead, studying becomes an asset to improve their competitive edge in the labor market. (Angoitia and Rahona, 2007); 2) a significant part of the working class jobs and trades more available to the less advantaged social class women within their social milieu (mechanics, electricians, construction workers among others) are not only traditionally masculine (and still laden with a discouraging gender bias) but don't require a higher education degree, while an increasing part of the traditionally feminine trades (nurses and teachers, to name but two of the most relevant ones) have been integrated into higher education systems (Berggren, 2008). In summary, overrepresentation of the most advantaged class can be explained by the convergence of several circumstances: (1) a more balanced gender distribution within the most advantaged social class (51.6 / 48.4); (2) a higher probability of men choosing best valued degrees as an effect of gender stereotypes (56/15); and (3) a greater class effect (strategic encouragement, preexisting professional female roles) counteracting prevailing gender constructs in women from the advantaged social class compared to women from the less advantaged social class.

Consequently, we can conclude that economic modernization and educational expansion have not put an end to the influence of social origin on occupational achievement and status. When educational expansion plateaued after having significantly reduced vertical stratification, horizontal stratification by degrees gained strength as a strategy of class differentiation and achievement of status mostly used by the most advantaged social class.

With regard to the limitations of our study and directions for future research, we would like to point out at several issues. First, although the sample handled in this study covers a wide time span and a large number of students, it is confined to a single university within a province with specific economic and social characteristics. Consequently, further research is needed to assess whether our hypothesis still hold true when applied to the whole of Spain and whether the EMI theory is valid in all phases if the life cicle of a higher education system.

In second place, handling such a large and longitudinal sample as the one used in this study, although it may have help increase the validity of the results, it has also posed important methodological challenges. The word count allowed to academic paper by all journals have inescapably required a certain level of reductionism. In particular, we had decide to leave out of the analysis data from more recent years. Although we don't believe this has hampered in any way the validity of the results, we must recognize, however, that it has at least prevented us from tackling an interesting issue, namely, the impact that the recent economic crisis has exerted on relation between the gender and social class variables and the choice of degree. 
In third place, first enrollment records have proven to be a very rich source of information to study the expectations and educational strategies of university students and their families. However, some students are always expected to change degree at some point of time after their first enrollment and there is always certain amount of dropouts. Hence, another possible exploitation of the data would be to analyze the dropout rate, the success or completion rate and the number of years invested by the students, differentiating by sex/gender and social class.

\section{BIBLIOGRAPHY}

Angoitia, M. \& Rahona, M. (2007). Evolución de la educación universitaria en España: diferentes perspectivas y principales tendencias (1991-2005). Revista de educación, (344), 219-221.

Atkinson, J. W. (1957). Motivational determinants of risk-taking behavior. Psychological review, 64(6p1), 359.

Ariño, A., Villarroya, A. A., Llopis, L., \& Goig, R. L. (2011). ¿ Universidad sin clases? Condiciones de vida de los estudiantes universitarios en España (Eurostudent IV). Ministerio de Educación.

Barone, C., \& Ortiz, L. (2011). Overeducation among European university graduates: A comparative analysis of its incidence and the importance of higher education differentiation. Higher Education, 61, 325-337.

Balint, Blanka (2013). «The Role of Social Capital in Avoiding Over-education (English version)». Re- vista Romana de Sociologie, 1-2: 101-126.

Bell, Daniel (1972).«On Meritocracy and Equality». The Public Interest, 29: 29-68.

Bell, Daniel (1973). The coming of the industrial society. NY: Basic Books.

Berggren, C. (2008). Horizontal and vertical differentiation within higher educationgender and class perspectives. Higher Education Quarterly, 62(1-2), 20-39.

Blau, P. M. y Duncan, O. D. (1967). The American Occupational Structure. New York: Wiley.

Bricall, J.M. (2000). Informe universidad 2000. España. Conferencia de Rectores de la Universidades Españolas (CRUE)

Brunello, G., \& Schlotter, M. (2011). Non cognitive skills and personality traits: Labour market relevance and their development in education \& training systems, IZA Discussion Paper No. 5743.

Breen, R. (Ed.). (2004). Social mobility in Europe. Oxford: Oxford University Press.

Breen, R., \& Goldthorpe, J. H. (2001). Class, mobility and merit the experience of two British birth cohorts. European sociological review, 17(2), 81-101. 
Breen, R., \& Goldthorpe, J. H. (1997). Explaining educational differentials towards a formal rational action theory. Rationality and society, 9(3), 275-305.

Carabaña, J., 1984. Modesto intento de interpretación de las tasas femeninas de escolaridad. Revista de Educación, 275, pp. 19-41.

Carabaña, J. (2004). Educación y movilidad social. En V. Navarro (Coord.), El estado de bienestar en España, 246-289. Madrid: Tecnos.

Charles, M., \& Bradley, K. (2009). Indulging our gendered selves? Sex segregation by field of study in 44 countries. American journal of sociology, 114(4), 924-976.

Charles, M., \& Bradley, K. (2002). Equal but separate? A cross-national study of sex segregation in higher education. American Sociological Review, 573-599.

Consejo de Coordinación Universitaria, C. (2002). Catálogo de Indicadores del sistema universitario público español. Madrid: MEC.

Crompton, R. (1994). Clase y estratificación. Una introducción a los debates actuales. Madrid. Tecnos.

de León Álvarez, M. A. G., \& de Cortázar Nebreda, M. L. G. (1992). Universidades y universitarios (1970-1990). Revista de educación, (1), 89-107.

Erikson, R. and Goldthorpe, J. H. (1992) The Constant Flux. A Study of Class Mobility in Industrial Societies. Oxford: Clarendon Press

Fachelli, S., \& Navarro-Cendejas, J. (2014). ¿La universidad española suaviza las diferencias de clase en la inserción laboral? 1 Does the Spanish university smoothed class differences in labour insertion?. Revista de educación $n^{\circ} 364$. Abril-Junio 2014, 364, 286119.

Francis, B. (2000). Boys, girls, and achievement: Addressing the classroom issues. Londres, Routledge.

Gabay-Egozi, Limor; Shavit, Yossi; Yaish, Meir; (2015) Gender Differences in Fields of Study: The Role of Significant Others and Rational Choice Motivations. Eur Sociol Rev, 31 (3): 284-297. doi: 10.1093/esr/jcu090

Grañeras, M. (2003). Trayectorias personales y profesionales de mujeres con estudios tradicionalmente masculinos. Madrid: Instituto de la Mujer.

Grusky, D. B., \& Sørensen, J. B. (1998). Can Class Analysis Be Salvaged? 1. American Journal of Sociology, 103(5), 1187-1234.

Haim, E. B., \& Shavit, Y. (2013). Expansion and inequality of educational opportunity: a comparative study. Research in Social Stratification and Mobility, 31, 22-31.

Inglehart, R. (1997). Modernization and postmodernization: Cultural, economic, and political change in 43 societies (Vol. 19). Princeton, NJ: Princeton University Press.

Jackson, Michelle (2001). «Meritocracy, Education, and Occupational Attainment: What Do Employers Really See as Merit?». Sociology Working Papers, University of Oxford, 2001-03. 
Jackson, R. M. (1998). Destined for equality. The Inevitable Rise of Women's Status. Cambridge, Mass.: Harvard University Press.

Latiesa, M. (Ed.). (1986). Demanda de educación superior y rendimiento académico en la Universidad: comunicaciones presentadas a las Jornadas Internacionales sobre Demanda de Educación Superior... Centro Nacional de Investigación y Documentación Educativa.

Marqués, I. y Gil-Hernández, C.J. (2015). "Social Origins and Over- Education of Spanish University Graduates: Is Access to the Service Class Merit-Based?". Revista Española de Investigaciones Sociológicas, 150: 89-112.

Monreal, J., Viñao, A., y otros. "Educación Universitaria. Realidad y expectativas", en Monreal, J. (ed.), Población y estructura educativa, ICE de la Universidad de Murcia, 1982.

Mora, J. G. (1997). Equity in Spanish higher education. Higher Education, 33, 233249. doi:10.1023/A: 1002950227350.

Mora, J. G., Garcia-Montalvo, J., \& Garcia-Aracil, A. (2000). Higher education and graduate employment in Spain. European Journal of Education, 35(2), 229-237.

Navarro-Guzmán, C., \& Casero-Martínez, A. (2012). Análisis de las diferencias de género en la elección de estudios universitarios. Estudios sobre educación, 22, 115-132.

Lin, N. (1999). Social networks and status attainment. Annual Review of Sociology, $25,467-487$.

O.C.D.E., 1986. L'Enseignement au féminin. Etudes internationales sur la fafon dont filles et garçons sont élevés et instruits. París, O.C.D.E.

Pérez, F., y Serrano, L. (1998). Capital humano, crecimiento económico y desarrollo regional en España (1964-1997). Fundació Bancaixa.

Portes, A. (2013). Sociología económica, una investigación sistemática (Vol. 9). CISCentro de Investigaciones Sociológicas.

Raftery, A. E., \& Hout, M. (1993). Maximally maintained inequality-expansion, reform, and opportunity in Irish education 1921-75. Sociology of Education, 66(1), 41-62.

Ramirez, F. O., \& Wotipka, C. M. (2001). Slowly but surely? The global expansion of women's participation in science and engineering fields of study, 1972-92. Sociology of Education, 231-251.

Reimer, D., Noelke, C., \& Kucel, A. (2008). Labor market effects of field of study in comparative perspective an analysis of 22 European countries. International Journal of Comparative Sociology, 49(4-5), 233-256.

Rivera, Lauren A. (2012). «Hiring as Cultural Matching: The Case of Elite Professional Service Firms.» American Sociological Review, 77: 999-1022.

Rose, D., \& Harrison, E. (Eds.). (2014). Social class in Europe: An introduction to the European socio-economic classification. Routledge. 
Salvador, L., \& García-Valcárcel, A. (1989). Rendimiento académico en la universidad de Cantabria: abandono y retraso en los estudios (No. 35). Ministerio de Educación.

Treiman, D. J. (1970). Industrialization and social stratification. Sociological Inquiry, 40(2), 207-234.

Tholen, G., Brown, P., Power, S., \& Allouch, A. (2013). The role of networks and connections in educational elites' labour market entrance. Research in Social Stratification and Mobility, 34, 142-154.

Triventi, M. (2013a). The role of higher education stratification in the reproduction of social inequality in the labor market. Research in Social Stratification and Mobility, $32,45-63$.

Triventi, M. (2013b). Stratification in higher education and its relationship with social inequality: A comparative study of 11 European countries. European Sociological Review, 29(3), 489-502.

UNESCO (2006). International Standard Classification of Education: ISCED 1997.

http://www.uis.unesco.org/Library/Documents/isced97-en.pdf

\section{ANEXXES}

ANNEX I: Occupation of parents categories

\begin{tabular}{|l|l|}
\hline $\begin{array}{c}\text { CATEGORIES USED FOR THE 18 ACADEMIC YEARS } \\
\text { (some of them only show a change in therminology) }\end{array}$ & FINAL AGREGGATE \\
\hline - Private Company CEO or public administration cadre & $\begin{array}{l}\text { Private companies and public } \\
\text { administration managers }\end{array}$ \\
- Company managers. & \\
\hline
\end{tabular}




\begin{tabular}{|l|l|}
\hline - Professionals with university or postsecondary degree & Professionals \\
- Technicians, scientists and intellectual professions & \\
\hline - Support technicians and other support professions & Clerical workers \\
- Clerks and service sector employees & \\
- Accounting and administrative employees & \\
- Employees in administrative positions & Armed forces \\
\hline - Armed forces & \\
- Military related professions & \\
- Armed forces professionals & \\
\hline - Skilled workers in agriculture and fishing & Manual workers \\
- Craftsmen and skilled workers in manufacturing, & \\
- Construction and mining industries & \\
- Installation and machinery operators and assemblers & \\
- Machinery operators in industry & \\
- Skilled workers and operators of machines in the industry & \\
- Unskilled workers & \\
- Catering workers, personal and private security services, & \\
and shop clerks & \\
\hline - Pensioners & \\
- Homemaking & \\
- Unpaid work & \\
- Unemployed & \\
\hline
\end{tabular}

ANNEX II: educational level of parents categories.

We have adapted the category system used by the UA to the I International Standard Classification of Education(ISCED 1997) used by UNESCO (UNESCO 2006), which is also the most common standard used in comparative studies on higher education systems, such as the Eurostudent IV (Ariño et al., 2003).

\begin{tabular}{|l|c|}
\hline - ISCED 97 levels 0-2 & $\begin{array}{c}\text { - No education/ Illiterate / ESO, EGB, Elementary } \\
\text { Baccalaureate / primary / First grade / Primary } \\
\text { studies }\end{array}$ \\
& $\begin{array}{c}\text { (Spanish version on the UA form: Sin estudios/ } \\
\text { Analfabeto/ESO, EGB, Bachillerato Elemental/ } \\
\text { Primarios completos/Primer grado/Estudios } \\
\text { primarios) }\end{array}$ \\
\hline - ISCED 97 levels 3-4 & $\begin{array}{c}\text { Baccalaureate or equivalent/secondary studies/ } \\
\text { Intermediate and Higher Level Vocational Training } \\
\text { Program }\end{array}$ \\
& $\begin{array}{c}\text { Spanish version on the UA form :Bachillerato } \\
\text { superior o asimilados/Estudios secundarios/FP } \\
\text { Grado Medio y Superior }\end{array}$ \\
\hline
\end{tabular}




\section{ANNEX III: Logit Binomial Analysis}

Our categories have been correlated with those established by the International Standard Classification of Occupations 2008 (ISCO-08) (ISCO08), used by Eurostat.

\begin{tabular}{|c|c|c|c|c|c|c|c|c|c|}
\hline & & $\operatorname{Exp}(B)$ & Wald & \multicolumn{2}{|c|}{$\begin{array}{l}\text { I.C. } 95.0 \% \text { for } \\
\operatorname{EXP(B)}\end{array}$} & \multicolumn{2}{|c|}{ ODDS } & $\mathrm{P}$ & \\
\hline Manual workers & OCU.PA.Eurost.I & & 56.194 & & & & & & \\
\hline 3 Armed forces & $\begin{array}{c}\text { OCU.PA.Eurost.I(1 } \\
\text { ) }\end{array}$ & $1.279 *$ & 6.617 & 1.060 & 1.543 & 0.23 & 0.18 & 0.19 & 0.15 \\
\hline 4 Clerical workers & $\begin{array}{c}\text { OCU.PA.Eurost.I(2 } \\
)\end{array}$ & $0.929 *$ & 4.637 & 0.869 & 0.993 & 0.17 & 0.18 & 0.14 & 0.15 \\
\hline 5 Professionals & $\begin{array}{c}\text { OCU.PA.Eurost.I(3 } \\
\text { ) }\end{array}$ & $1.120^{*}$ & 5.187 & 1.016 & 1.234 & 0.20 & 0.18 & 0.17 & 0.15 \\
\hline $\begin{array}{c}6 \text { Private companies } \\
\text { and public } \\
\text { administration } \\
\text { managers }\end{array}$ & $\begin{array}{c}\text { OCU.PA.Eurost.I(4 } \\
\text { ) }\end{array}$ & $1.260 *$ & 27.673 & 1.156 & 1.373 & 0.23 & 0.18 & 0.19 & 0.15 \\
\hline $\begin{array}{c}\text { REF. Others: } \\
\text { pensioners. } \\
\text { Homemakers, etc. }\end{array}$ & OCU.MA.Eurost.I & & 17.221 & & & 0.18 & 0.18 & 0.15 & 0.15 \\
\hline 2 Manual workers & $\begin{array}{l}\text { OCU.MA.Eurost.I( } \\
1)\end{array}$ & $0.886^{*}$ & 13.869 & 0.831 & 0.944 & 0.16 & 0.18 & 0.14 & 0.15 \\
\hline 3 Armed forces & $\begin{array}{l}\text { OCU.MA.Eurost.I( } \\
\text { 2) }\end{array}$ & 0.991 & 0.001 & 0.543 & 1.810 & 0.18 & 0.18 & 0.15 & 0.15 \\
\hline 4 Clerical workers & $\begin{array}{l}\text { OCU.MA.Eurost.I( } \\
3)\end{array}$ & $0.914 *$ & 5.711 & 0.850 & 0.984 & 0.17 & 0.18 & 0.14 & 0.15 \\
\hline 5 Professionals & $\begin{array}{l}\text { OCU.MA.Eurost.I( } \\
4)\end{array}$ & 0.992 & 0.021 & 0.885 & 1.112 & 0.18 & 0.18 & 0.15 & 0.15 \\
\hline $\begin{array}{c}6 \text { Private companies } \\
\text { and public } \\
\text { administration } \\
\text { managers }\end{array}$ & $\begin{array}{l}\text { OCU.MA.Eurost.I( } \\
5)\end{array}$ & 1.003 & 0.002 & 0.874 & 1.152 & 0.18 & 0.18 & 0.15 & 0.15 \\
\hline ISCED 97 levels 0-2 & EST.PA.Eur.I & & 111.813 & & & 0.18 & 0.18 & 0.15 & 0.15 \\
\hline $\begin{array}{l}\text { ISCED } 97 \text { levels 3-5 } \\
2 \text { MEDIA }\end{array}$ & EST.PA.Eur.I(1) & $1.271 *$ & 37.826 & 1.178 & 1.372 & 0.23 & 0.18 & 0.19 & 0.15 \\
\hline
\end{tabular}




\begin{tabular}{|c|c|r|r|r|r|r|r|r|r|}
\hline $\begin{array}{c}\text { ISCED 97 levels 5-6 } \\
\text { 3 SUPERIOR }\end{array}$ & EST.PA.Eur.I(2) & $1.569^{*}$ & 105.467 & 1.440 & 1.710 & 0.28 & 0.18 & 0.22 & 0.15 \\
\hline ISCED 97 levels 0-2 & EST.MA.Eur.I & & 25.708 & & & 0.18 & 0.18 & 0.15 & 0.15 \\
\hline $\begin{array}{c}\text { ISCED 97 levels 3-4 } \\
\text { 2 MEDIA }\end{array}$ & EST.MA.Eur.I(1) & $1.209^{*}$ & 21.207 & 1.115 & 1.310 & 0.22 & 0.18 & 0.18 & 0.15 \\
\hline $\begin{array}{c}\text { ISCED 97 levels 5-6 } \\
\text { Men }\end{array}$ & EST.MA.Eur.I(2) & $1.196^{*}$ & 12.906 & 1.085 & 1.318 & 0.22 & 0.18 & 0.18 & 0.15 \\
\hline & SEX recod(1) & $6.943^{*}$ & 5509.777 & 6.597 & 7.307 & 1.26 & 0.18 & 0.56 & 0.15 \\
\hline
\end{tabular}

\begin{tabular}{|c|c|}
\hline Universe & $\begin{array}{c}\text { First year students enrolled in the best and worst valued by the labor market } \\
\text { degrees* }\end{array}$ \\
\hline $\begin{array}{c}\text { Cases included in the analysis } \\
\text { Chi-square value }\end{array}$ & $\begin{array}{c}32910 \text { (male and female students who enroll for the first time in one of the best } \\
\text { and worst valued by the labor market degrees. }\end{array}$ \\
\hline Sig. Chi-square & 6932.704 \\
\hline Log-likelihood & 0.000 \\
\hline Nagelkerke r square & 36580.365 \\
\hline SPECIFICITY & 0.259 \\
\hline SENSITIVITY & 69.3 \\
\hline Global percentage & 75.4 \\
\hline
\end{tabular}

Source: Authors 